\title{
A Study on Dropout among Muslim Children in the Nilgiris District
}

\author{
P. Shanmugam ${ }^{1 *}$ and F. M. Shabnaz ${ }^{2}$ \\ ${ }^{1}$ Assistant Professor, Department of Economics, Bharathiar University, Coimbatore, Tamil Nadu, India; \\ bushanmugam@gmail.com \\ ${ }^{2}$ Reserach Scholar, Department of Economics, Bharathiar University, Coimbatore, Tamil Nadu, India
}

\begin{abstract}
Many Muslim countries including Pakistan tried to promote the literacy level of their people. Post independent India has been implementing various schemes to promote the literacy level in the country, but still the dropout persists. Particularly among the Muslim children it is increasing by an alarming rate due to their social and cultural phenomenon. With this background a study is undertaken among the Muslim children living in the Nilgiris district to find out their socio-demographic characteristics and analyse the causes for their dropout.
\end{abstract}

Keywords: Dropout, Education, Muslim Children, School Children

\section{Introduction}

Kneller et al. ${ }^{1}$ asserted that education is the process by which a society, through schools, colleges, universities and other institutions deliberately transmits its cultural heritage from one generation to another. For this reason, education is the highest tool for swift development in any community particularly, to the Muslims it enables them to overcome their economic problems because, economic dependency is the major cause for their low status. Further, Indian Muslims are lagging behind in pursuing higher literacy due to their poor financial conditions, lack of schools nearby, high dropouts, not aspiring to survive educationally, dearth of resources in the available schools, disinterestedness in education, and absence of inspiring leadership in the community. Though, Muslims are found all over India, they are largely concentrated in 12 states whereby they constitute more than 10 per cent of the state population. It has also been reported that the dropout of the Muslim children from schools and other educational institutions is of higher rate. According to Shazli and Sana Asma ${ }^{2}$, female literacy among the Muslims is also significantly low and this is one of the important reasons of ignorance and illiteracy in Muslim community. Hence, this paper focuses on the socio-demographic characteristics of the Muslim households and the causes for dropout among Muslim children in the Nilgiris district.

\section{Review of Literature}

Pillai et al. ${ }^{3}$ estimated the rate of dropout in primary education to perceive the socio- financial reasons of dropout. Devi ${ }^{4}$ made an investigation about the issues of dropouts in primary school and concluded that there was no uniformity within the rate of dropouts for the entire primary course at the lower primary stage. Okumu and Ibrahi et al. ${ }^{5}$ conducted a study on the socio-economic determinants of primary school dropouts. Tyler and Lofstrom ${ }^{6}$ suggested the alternative pathways to recover the dropouts. Anitha et al. ${ }^{7}$ concluded that the parents' attitude towards girl child's education was positively related to the increasing school dropouts. Sang, et al. ${ }^{8}$ analysed the dropout level of public secondary schools in relation to selected school characteristics. Afsar Ali ${ }^{9}$ made a comparative study on the dropout problems in primary education among Muslim community in relation to gender and economic status. Devkota and Bugale ${ }^{10}$ pointed out that the major reasons for the dropout were economic status, family background, access and equity, quality degeneration, public-private dichotomy.

*Author for correspondence 
Shahidul and Zehadul Karim ${ }^{11}$ probed the factors contributing to school dropout among girls. Thus the above literature reveals that there have been multiple reasons for the dropout among children. However there were very limited studies on dropout of Muslim children. Hence, a fresh study is warranted to analyse the problems associated with the education and dropout among Muslim children

\section{Objectives of the Study}

- To analyze the socio-demograpic characteristics of Muslim households in the study area.

- To identify the causes for dropout among the Muslim children in the study area.

\section{Methodology}

\subsection{Collection of Data}

The data required for this study were collected from primary source. The primary data were collected from the households of the Nilgiris. In total, 109 households were selected in the Nilgiris district. A pre-tested interview schedule was used to collect the data for the academic year 2015-2016.

Tamil Nadu is one of the leading states in literacy level. Among all the districts of Tamil Nadu the Nilgiris stood at fourth position in literacy rate ${ }^{12}$. But the dropout ratio is somewhat high in the Nilgiris district particularly among Muslims $^{13}$. From the four blocks i.e., Coonoor, Ooty,
Kotagiri and Gudalur, three blocks were chosen purposively. The reason for not choosing the Gudalur block was because in this block majority of the people were Keralite Muslims, and they have schools for religious as well as general education and in Gudalur block literacy level was as high as 89.12\% (SSA-2010-2011), while the dropout level was low. Whereas, in Coonoor, Ooty and Kotagiri blocks Muslim dropout rate was high. By using convenient sampling technique 109 households were selected from Muslim dominated areas for the study, provided there was at least one child dropout in each household. Thus, 40 households from Coonoor block, 35 households from Kotagiri block and 34 households from Ooty block were selected for the study.

\subsection{Tools of Analysis}

Simple tabular statements were prepared to work out percentages and average values. The study is based on empirical analysis with various statistical and econometric tools like, Garrett's Ranking Technique and Binary Logistic Regression.

\subsection{Hypothesis}

The dropout among the Muslim children children is positively associated with the economic factors.

\section{Results and Discussion}

\subsection{Socio-demographic Characteristics - Percentage Analysis}

The socio-demographic characteristics among the Muslim households living in the Nilgiris are shown in tables 1 to 5 .

Table 1. Age and Gender wise Classification of Respondents

\begin{tabular}{llllll}
\hline SI.No & Age & Coonoor & Kotagiri & Ooty & Total \\
\hline 1. & Below 15 & 2 & 1 & 4 & 7 \\
& & $(5.0)$ & $(2.9)$ & $(11.8)$ & $(6.4)$ \\
\hline 2. & 15 to 20 & 32 & 30 & 7 & 88 \\
& & $(80.0)$ & $(85.7)$ & $(76.5)$ & $(80.7)$ \\
\hline 3 & 20 and above & 6 & 4 & 4 & 14 \\
& & $(15.0)$ & $(11.4)$ & $(11.8)$ & $(12.8)$ \\
\hline & Gender & & & & \\
1. & Male & 11 & 10 & 16 & 37 \\
& & $(27.5)$ & $(28.6)$ & $(47.1)$ & $(33.9)$ \\
2. & Female & 29 & 25 & 18 & 72 \\
& & $(72.5)$ & $(71.4)$ & $(52.9)$ & $(66.1)$ \\
& Total & 40 & 35 & 34 & 109 \\
& & $(100)$ & $(100)$ & $(100)$ & $(100)$ \\
\hline
\end{tabular}

Source: Computed from primary data 
Table 2. Education wise Classification of Respondents

\begin{tabular}{llllll}
\hline SI.No & Education & Coonoor & Kotagiri & Ooty & Total \\
\hline 1. & Primary & 0 & 0 & 1 & 1 \\
& & $(0)$ & $(0)$ & $(2.9)$ & $(0.9)$ \\
\hline 2. & Middle & 13 & 11 & 13 & 37 \\
& & $(32.5)$ & $(31.4)$ & $(38.2)$ & $(33.9)$ \\
\hline 3. & Secondary & 17 & 12 & 5 & 34 \\
& & $(42.5)$ & $(34.3)$ & $(14.7)$ & $(31.2)$ \\
4. & Higher secondary & 10 & 12 & 15 & 37 \\
& & $(25.0)$ & $(34.3)$ & $(44.1)$ & $(33.9)$ \\
& Total & 40 & 35 & 34 & 109 \\
& & $(100)$ & $(100)$ & $(100)$ & $(100)$ \\
\hline
\end{tabular}

Source: Computed from primary data

Note: Figures in parentheses are percentage to the total

Table 3. Occupation wise Classification of the Head of the Households

\begin{tabular}{llllll}
\hline SI.No & Occupation & Coonoor & Kotagiri & Ooty & Total \\
\hline 1. & Government & 21 & 14 & 17 & 52 \\
& & $(52.5)$ & $(40.0)$ & $(50.0)$ & $(47.7)$ \\
\hline 2. & Business & 10 & 8 & 6 & 24 \\
& & $(25.0)$ & $(22.9)$ & $(17.6)$ & $(22.6)$ \\
3. & Coolie & 3 & 3 & 3 & 9 \\
& & $(7.5)$ & $(8.6)$ & $(8.8)$ & $(8.3)$ \\
4. & Private concerns & 6 & 10 & 8 & 24 \\
& & $(15.0)$ & $(28.6)$ & $(23.5)$ & $(22.0)$ \\
& Total & 40 & 35 & 34 & 109 \\
& & $(100)$ & $(100)$ & $(100)$ & $(100)$ \\
\hline
\end{tabular}

Source: Computed from primary data

Note: Figures in parentheses are percentage to the total

Age is an important factor which describes the earning capacity of a person and also his household. The age of the respondents of the study area is given in Table 1. In total, $80.7 \%$ of respondents are of the age from 15 to 20 years, whereas Kotagiri has the highest proportion of $85.7 \%$ of the respondents in the age group of 15 to 20 . Regarding the gender wise classification of respondents, in all, female out proportioned at $66.1 \%$ as against male at $33.9 \%$. Among the blocks, Coonoor has the highest proportion of $73 \%$ female when compared with others.

The education wise classification of the respondents is presented in Table 2. It could be observed that more than one third (33.9\%) of the respondents are middle and higher secondary education holders and a little less than that $(31.2 \%)$ have studied up to secondary education. But in the case of up to primary education only, the proportion of the respondents was meager at $(0.9 \%)$.

Table 3 depicts the details of occupation of the head of the households. In total, nearly one half $(47.7 \%)$ of the head of the households are Government employees, followed by business people (22.6\%), private employees (22\%) and coolies (8.3\%). Among the blocks, in Coonoor, more than one half (52.2\%) of the households are Government employees.

Primary sources of income of the surveyed households are presented in Table 4, which are of eight categories. In total, the income from daily wage shows the highest proportion of respondents at $40.4 \%$ followed by profit from business at $31.2 \%$. But among the blocks, in Ooty profit from business shows the highest proportion of respondents at $38.2 \%$, while in Coonoor and Kotagiri blocks the households' income from daily wage dominated other sources.

Table 5 reveals the facility available in schools of the study area as confirmed by the respondents. In total, three fourths $(75.2 \%)$ of the respondents agreed that they have adequate teachers in their schools, which also is confirmed in each block. Availability of good library in their schools has been agreed upon by a maximum of $42.9 \%$ of the respondents in Kotagiri block, while in Coonoor and Ooty 
Table 4. Primary Sources of Income of the Households

\begin{tabular}{llllll}
\hline $\begin{array}{l}\text { SI. } \\
\text { No }\end{array}$ & Income & Coonoor & Kotagiri & Ooty & Total \\
\hline 1. & Service & & & & \\
\hline & & $(10.0)$ & $(17.1)$ & $(17.6)$ & $(14.7)$ \\
\hline 2. & Industrial Works & 4 & 3 & 2 & 9 \\
& & $(10.0)$ & $(8.6)$ & $(5.9)$ & $(8.3)$ \\
\hline 3. & Daily Wage & 16 & 16 & 12 & 44 \\
& & $(40.0)$ & $(45.7)$ & $(35.3)$ & $(40.4)$ \\
\hline 4. & Rent from Property (Excluding Expenses) & 1 & 1 & 0 & 2 \\
& & $(2.5)$ & $(2.9)$ & $(0)$ & $(1.8)$ \\
\hline 5. & Interests and dividends from Bonds, & 2 & 1 & 0 & 3 \\
& Shares and Bank A/C & $(5.0)$ & $(2.9)$ & $(0)$ & $(2.8)$ \\
\hline 6. & Profit from Business (Excluding Expenses) & 12 & 9 & 13 & 34 \\
& & $(30.0)$ & $(25.7)$ & $(38.2)$ & $(31.2)$ \\
\hline 7. & Pensions, Annuities, Benefits & 5 & 6 & 4 & 15 \\
& & $(12.5)$ & $(17.1)$ & $(11.8)$ & $(13.8)$ \\
\hline 8. & Other Money Income & 3 & 2 & 5 & 10 \\
& & $(7.5)$ & $(5.7)$ & $(14.7)$ & $(9.2)$ \\
\hline & Total & 40 & 35 & 34 & 109 \\
& & $(100)$ & $(100)$ & $(100)$ & $(100)$ \\
\hline
\end{tabular}

Source: Computed from primary data Note: Figures in parentheses are percentage to the total

Table 5. Facilities Available in School

\begin{tabular}{llllll}
\hline SI.No. & Facility & Coonoor & Kotagiri & Ooty & Total \\
\hline 1. & Adequate teachers & 29 & 27 & 26 & 82 \\
& & $(75.5)$ & $(77.1)$ & $(76.5)$ & $(75.2)$ \\
\hline 2. & Adequate class rooms & 15 & 13 & 15 & 43 \\
& & $(37.5)$ & $(37.1)$ & $(44.1)$ & $(39.4)$ \\
\hline 3. & $\begin{array}{l}\text { Drinking water /play ground / } \\
\text { play things }\end{array}$ & 16 & 11 & 14 & 41 \\
& Good library & $(40.0)$ & $(31.4)$ & $(41.2)$ & $(37.6)$ \\
\hline & & $(35.0)$ & 15 & 8 & 37 \\
& Total & 40 & $(42.9)$ & $(23.5)$ & $(33.9)$ \\
& & $(100)$ & 35 & 34 & 109 \\
\end{tabular}

Source: Computed from primary data Note: Figures in parentheses are percentage to the total

Table 6. Ranking of Personal Causes for Dropout among the Respondents

\begin{tabular}{lllll}
\hline Sl.No. & Factors & $\begin{array}{l}\text { Coonoor } \\
\text { Rank }\end{array}$ & $\begin{array}{l}\text { Kotagiri } \\
\text { Rank }\end{array}$ & $\begin{array}{l}\text { Ooty } \\
\text { Rank }\end{array}$ \\
\hline & Personal Reasons & & & \\
\hline 1. & Lack of interest in learning & II & I & I \\
\hline 2. & Poor attendance & I & II & II \\
\hline 3. & Early Marriage and Pregnancy & III & III & III \\
\hline 4. & Bad company and habits & IV & IV & IV \\
\hline
\end{tabular}

Source: Computed from primary data 
blocks, it was agreed upon by a minimum of respondents only at $35 \%$ and $23.5 \%$ respectively.

\subsection{Causes of Dropout-Garrett's Ranking Analysis}

The causes of dropout among Muslim children were probed from six dimensions namely, personal causes, economic causes, religious causes, health related causes, social and cultural causes, and the causes of school related issues. Various factors related to these six categories of causes were analysed by employing Garrett's Ranking Technique to bring out the most significant reasons causing the dropout among Muslim children as shown in tables-6 to 11 .

Table 6 sketches out the ranking of personal causes for dropout among the Muslim children of the study blocks. In Kotagiri and Ooty blocks the reason of 'lack of interest in learning' ranks first and 'poor attendance' as second, while it is ranked vice versa in Coonoor block. 'Early marriage and pregnancy' and 'bad company and habit' are ranked third and fourth in all the three blocks.

Table 7. Ranking of Economic Causes for Dropout among the Respondents

\begin{tabular}{|c|c|c|c|c|}
\hline SI.No & Factors & $\begin{array}{l}\text { Coonoor } \\
\text { Rank }\end{array}$ & $\begin{array}{l}\text { Kotagiri } \\
\text { Rank }\end{array}$ & $\begin{array}{l}\text { Ooty } \\
\text { Rank }\end{array}$ \\
\hline & $\begin{array}{l}\text { Economic } \\
\text { Reasons }\end{array}$ & & & \\
\hline 1. & $\begin{array}{l}\text { Unable to pay } \\
\text { education and } \\
\text { tuition fee }\end{array}$ & II & II & II \\
\hline 2. & $\begin{array}{l}\text { High transport } \\
\text { expenses }\end{array}$ & III & III & III \\
\hline 3. & $\begin{array}{l}\text { High hostel } \\
\text { expenses }\end{array}$ & IV & IV & IV \\
\hline 4. & $\begin{array}{l}\text { Poor family } \\
\text { income }\end{array}$ & I & I & I \\
\hline 5. & To earn money & $\mathrm{V}$ & $\mathrm{V}$ & $\mathrm{V}$ \\
\hline 6. & $\begin{array}{l}\text { Domestic work } \\
\text { burden }\end{array}$ & IV & IV & IV \\
\hline
\end{tabular}

Source: Computed from primary data

Ranking of economic causes for dropout among the Muslim children are presented in Table 7, wherein 'poor family income' ranks first followed by 'unable to pay education and tuition fee' ranking second, 'high transport expenses' ranking third, 'high hostel expenses' ranking fourth, 'to earn money' ranking fifth and 'domestic work burden' ranking sixth in all the three blocks.
Table 8 shows the ranking of religious causes for dropout among the Muslim children. It can be noted that the reason of 'co-education in the school' has ranked first and 'no Muslim school nearby' as second in all the three blocks. 'Education decreases religiousness' ranked as third in case of Coonoor and Kotagiri blocks while as fourth in Ooty block.

Table 8. Ranking of Religious Causes for Dropout among the Respondents

\begin{tabular}{lllll}
\hline SI.No & Factors & $\begin{array}{l}\text { Coonoor } \\
\text { Rank }\end{array}$ & $\begin{array}{l}\text { Kotagiri } \\
\text { Rank }\end{array}$ & $\begin{array}{l}\text { Ooty } \\
\text { Rank }\end{array}$ \\
\hline 1. & $\begin{array}{l}\text { Religious } \\
\text { Reasons } \\
\text { Education } \\
\text { decreases } \\
\text { religiousness }\end{array}$ & III & III & I V \\
\hline 2. & $\begin{array}{l}\text { No facility for } \\
\text { further study } \\
\text { in the block }\end{array}$ & IV & IV & III \\
\hline 3. & $\begin{array}{l}\text { No Muslim } \\
\text { school nearby } \\
\text { Co-education } \\
\text { in the school }\end{array}$ & I & II & II \\
\hline 4. & I & I \\
\hline
\end{tabular}

Source: Computed from primary data

Table 9. Ranking of Health Related Causes for Dropout among the Respondents

\begin{tabular}{|lllll}
\hline SI.No & Factors & $\begin{array}{l}\text { Coonoor } \\
\text { Rank }\end{array}$ & $\begin{array}{l}\text { Kotagiri } \\
\text { Rank }\end{array}$ & $\begin{array}{l}\text { Ooty } \\
\text { Rank }\end{array}$ \\
\hline 1. & $\begin{array}{l}\text { Illness of the } \\
\text { student }\end{array}$ & V & V & II \\
\hline 2. & $\begin{array}{l}\text { Illness } \\
\text { of family } \\
\text { members }\end{array}$ & II & I & IV \\
\hline 3. & Puberty & I & II & V \\
\hline 4. & $\begin{array}{l}\text { Mal } \\
\text { nutrition }\end{array}$ & III & IV & III \\
\hline 5. & Disability & IV & III & I \\
\hline
\end{tabular}

Source: Computed from primary data

Ranking of health related causes for dropout among the Muslim children are presented in Table 9, wherein 'illness of family members' has ranked first in Kotagiri block, while as second in Coonoor block and as fourth in Ooty block. The reason of 'puberty' ranks first in Coonoor, as second in Kotagiri and as fifth in Ooty block. However, 'disability' has ranked first in Ooty block, as third in Kotagiri block and as forth in Coonoor block. 'Illness of the student' has 
ranked second in Ooty block, as fifth in both Coonoor and Kotagiri blocks. 'Mal Nutrition' has ranked third in Coonoor and Ooty blocks and as forth in Kotagiri block.

The Garrett ranking of social and cultural causes faced by the Muslim children are shown in Table 10. The reason of 'gender discrimination' has ranked first in both Coonoor and Kotagiri blocks, while as fifth in Ooty block. 'Way to brother' has ranked first in Ooty block which however, ranked third in Coonoor and Kotagiri blocks. 'Take care of siblings' has ranked second both in Kotagiri and Ooty blocks, while as fourth in Coonoor block. 'School is not important' has ranked second in Coonoor block, while as forth in Kotagiri and Ooty blocks. 'Eldest in school' has ranked third in Ooty block, whereas ranked fifth in both Coonoor and Kotagiri blocks.

Table 10. Ranking of Social and Cultural Causes for Dropout among the Respondents

\begin{tabular}{lllll}
\hline SI.No & Factors & $\begin{array}{l}\text { Coonoor } \\
\text { Rank }\end{array}$ & $\begin{array}{l}\text { Kotagiri } \\
\text { Rank }\end{array}$ & $\begin{array}{l}\text { Ooty } \\
\text { Rank }\end{array}$ \\
\hline & $\begin{array}{l}\text { Social and } \\
\text { Cultural Reasons }\end{array}$ & & & \\
\hline 1. & Way to brother & III & III & I \\
\hline 2. & $\begin{array}{l}\text { Take care of } \\
\text { siblings }\end{array}$ & IV & II & II \\
\hline 3. & Eldest in school & V & V & III \\
\hline 4. & $\begin{array}{l}\text { School is not } \\
\text { important }\end{array}$ & II & IV & IV \\
\hline 5. & $\begin{array}{l}\text { Gender } \\
\text { discrimination }\end{array}$ & I & I & V \\
\hline
\end{tabular}

Source: Computed from primary data

Ranking of School related issues causing dropout among the Muslim children are given in Table 11. 'No quality Education' has ranked first in Kotagiri block, while as second in Ooty block and as fourth in Coonoor block. The reason of 'far away' has ranked first in Coonoor block, whereas third in Kotagiri block and as fourth in Ooty block. 'Unsafe road' has ranked first in Ooty block and however ranked second in Kotagiri and Coonoor blocks. 'Difficulties in language' has ranked fourth in Kotagiri block, whereas third in both Coonoor and Ooty blocks.

\subsection{Testing of Hypothesis}

Though the dropout among the Muslim children was associated with many factors, economic reasons play a vital role. In this context a hypothesis is framed as below:

$\mathbf{H}_{1:}$ The dropout among the Muslim children is positively associated with the economic factors.
Table 11. Ranking of School Related Issues being the Causes for Dropout among the Respondents

\begin{tabular}{lllll}
\hline SI.No & Factors & $\begin{array}{l}\text { Coonoor } \\
\text { Rank }\end{array}$ & $\begin{array}{l}\text { Kotagiri } \\
\text { Rank }\end{array}$ & $\begin{array}{l}\text { Ooty } \\
\text { Rank }\end{array}$ \\
\hline & $\begin{array}{l}\text { School } \\
\text { Related Issues }\end{array}$ & & & \\
\hline 1. & $\begin{array}{l}\text { No quality } \\
\text { education }\end{array}$ & IV & I & II \\
\hline 2. & $\begin{array}{l}\text { Difficulties in } \\
\text { language }\end{array}$ & III & IV & III \\
\hline 3. & Far away & I & III & IV \\
\hline 4. & Unsafe road. & II & II & I \\
\hline
\end{tabular}

Source: Computed from primary data

The dropout of the Muslim children was taken as dependent variable while age, marital status, type of family, occupation of the head, income of the household, savings of the household, investment held, asset value, mothers' education and fathers' education were considered as independent variables to apply the Binary Logistic Regression Analysis ${ }^{14}$.

To interpret the binary logistic regression model, both odd and inverse odd ratio has been calculated and it is given in Table 12. The inverse odd ratio has been calculated for the co-efficient with negative sign or the odds ratios less than 1 . The odd ratio of the independent variables 'type of family', 'asset value' and 'mothers' education' is less than one. However, the co-efficient of 'asset value' and 'mothers' education' were statistically significant at 10 per cent level, while the same for 'type of family' stood significant at $5 \%$ level. The inverse odd ratio for 'type of family' interprets that the nuclear family has the dropout ratio 1.004 times more than joint family. Further, it can be perceived that those who are having high level of assets their family's dropout stood high about 0.001 times than those are having less assets. Related to 'education', the odd ratio suggests that there are more dropouts by 1.163 times in the family where the mothers are educated than in the family of uneducated mothers. Thus the hypothesis is proved i.e., there is positive association between dropout among the Muslim children and the economic factors, particularly 'asset value' held in the family. However the education of the mother also plays a greater role in the dropout of Muslim children.

\section{Key Findings}

- The socio-demographic analysis has exposed that $80.7 \%$ of respondents are of the age from 15 to 20 years; more than one third $(33.9 \%)$ of the respondents are middle 
Table 12. Binary Logistic Regression to Identify the Reasons for Muslim Dropouts

\begin{tabular}{|c|c|c|c|c|}
\hline SI.No & Variables & Beta & Odd ratio & Inverse Odd Ratio \\
\hline & Constant & -4.625 & .010 & - \\
\hline 1. & Age & 1.592 & 4.913 & - \\
\hline 2. & Marital Status & 1.936 & 6.929 & - \\
\hline 3. & Type of Family & $-.004^{*}$ & 0.996 & 1.004 \\
\hline 4. & Occupation of the head & 1.093 & 2.983 & - \\
\hline 5. & Income of the household & 1.727 & 5.624 & - \\
\hline 6. & Savings of the household & -2.680 & 0.069 & \\
\hline 7. & Investment held & 1.057 & 2.879 & - \\
\hline 8. & Asset Value & $-0.181^{\star *}$ & 0.834 & 0.001 \\
\hline 9. & Mothers' Education & $-0.151^{\star *}$ & 0.860 & 1.163 \\
\hline 10. & Fathers' Education & 1.495 & 4.459 & - \\
\hline $\begin{array}{l}-2 \text { Log } \\
\text { Cox \& } \\
\text { Nagelk } \\
\text { Chi-sq }\end{array}$ & $\begin{array}{l}\text { lihood } \\
\text { ell R Square } \\
\text { e R Square } \\
\text { e(10df) }\end{array}$ & $\begin{array}{l}70^{\mathrm{a}} \\
19 \\
45 \\
196\end{array}$ & $\begin{array}{l}\text { Sample Size } \\
\text { Level of Sigr } \\
* \text { Significant } \\
* * \text { Significar }\end{array}$ & $\begin{array}{l}\quad=109 \\
\text { cance }=0.000 \\
5 \% \text { level } \\
\text { t 10\% level }\end{array}$ \\
\hline
\end{tabular}

Source: Computed from primary data

and higher secondary education holders; nearly one half $(47.7 \%)$ of the head of the households are Government employees; the income from daily wage recorded the highest proportion of respondents at $40.4 \%$; and three fourths $(75.2 \%)$ of the respondents agreed that they have adequate teachers in their schools.

- Garrett's Ranking analysis of the causes of dropout among Muslim children has revealed that of various factors, the reasons of 'lack of interest in learning', 'poor family income', 'co-education in the school', 'illness of family members', 'gender discrimination', and 'no quality education' have ranked first.

- Binary Logistic Regression analysis has disclosed that there is a positive association between dropout among the Muslim children and the economic factors, particularly 'asset value' held in the family. However the education of the mother also plays a greater role in the dropout of Muslim children.

\section{Conclusion}

The level of education determines the entire socio-economic behaviour of a person and his family. In spite of various steps taken by the government, the dropout among Muslim children did not fall down as found in the study. The prime reasons for dropout among Muslim children were lack of interest in learning and low family income. The rate of female enrollment especially at the secondary school level is still significantly lower than that of male enrollment. Girls are becoming more likely to dropout from school than boys. The foremost reason for this is gender discrimination and co-education in school. So it is important to reduce the dropout among the Muslim children which definitely would reduce the unawareness among them and also control their financial problems in the study area.

\section{References}

1. Kneller, Heidegger, Death. Educational Theory. 1965; 15(3):169-264

2. Shazli T, Asma S. Educational Vision of Muslims in India: Problems and Concerns. International Journal of Humanities and Social Science Invention. 2015; 4(3):21-7.

3. Pillai B, Nair. A study of dropouts in primary education in Kerala, state Planning Board, Government of Kerala, Trivandrum, M.B. third survey of research in education, NCERT. 1980.

4. Devi KG. Problem of dropouts in primary schools of Manipur with special reference to Imphal Town囚 Ph.D, edu, BUCH Educational Survey. 1983-1988; 2:1267.

5. Ibrahim OM, Nakajijo A, Isoke D. Socio Economic Determinants of Primary School Dropout: The Logistic Model Analysis. Economic policy Research center. 2008; 1-28.

6. Tyler JH, Lofstrom M. Finishing High School: Alternative Pathways and Dropout Recovery. Magnus Lofstrom is a research fellow at the Public Policy Institute of California. 2009;19(1):77-103. 
7. Anitha S, Jasmine B, Deeba Lakshmi S. A study on school dropout; A data mining analysis. International Journals of Engineering Research and Technology. $2013 ; 2(6)$.

8. Sang Anthony KA. An Analysis on Dropout Levels of Public Secondary Schools in Kericho District in Relation to Selected School Characteristics. International Education Studies. 2013; 6(7):247-59.

9. Afsar A. A comparative study on the dropout problem in Primary Education among Muslim community in relation to gender and economic status. IOSR Journal of Humanities and Social Science (IOSR-JHSS). 2014; 19(12):76-8. Crossref

10. Prasad DS, Bagale S. Primary Education and Dropout in Nepal. Journal of Education and Practice. 2015;
6(4):153-7. ISSN 2222-1735 (Paper) ISSN 2222-288X (Online):.

11. Shahidul, Karim Z. Factors Contributing to School Dropout Among The Girls: A Review Of Literature. European Journal of Research and Reflection in Educational Sciences. 2015; 3(2):25-36.

12. Available from: http://www.census2011.co.in/census/ state/districtlist/tamil+nadu.html

13. Available from: http://www.ssa.tn.nic.in/statistics.htm

14. Mark Tranmer and Mark Elliot, Binary Logistic Regression. P. 1 - 43.

Available from: http://hummedia.manchester.ac.uk/ institutes/cmist/archive-publications/workingpapers/2008/2008-20-binary-logistic-regression.pdf 